\title{
High school learners views on benefits derived from attending career talks: Need for sound career guidance
}

\begin{tabular}{|c|c|}
\hline \multicolumn{2}{|c|}{$\begin{array}{l}\text { Authors: } \\
\text { Zamandlovu S. Makola }{ }^{1} \\
\text { Pumeza Saliwe }{ }^{1} \\
\text { Itumeleng Dube } \\
\text { Ramodungoane Tabane } \\
\text { Awelani V. Mudau } \\
\text { Aw }\end{array}$} \\
\hline $\begin{array}{l}\text { Affiliations: } \\
\text { 1Department } \\
\text { Resource Mar } \\
\text { Economic and } \\
\text { Sciences, Univ } \\
\text { South Africa, I } \\
\text { South Africa }\end{array}$ & $\begin{array}{l}\text { f Human } \\
\text { agement, } \\
\text { Management } \\
\text { ersity of } \\
\text { retoria, }\end{array}$ \\
\hline $\begin{array}{l}{ }^{2} \text { Department } \\
\text { Administratio } \\
\text { Management, } \\
\text { Management } \\
\text { University of } \\
\text { Pretoria, Sout }\end{array}$ & $\begin{array}{l}\text { f Public } \\
\text { and } \\
\text { Economic and } \\
\text { Sciences, } \\
\text { outh Africa, } \\
\text { Africa }\end{array}$ \\
\hline $\begin{array}{l}{ }^{3} \text { Department } \\
\text { of Education, } \\
\text { Education, Un } \\
\text { South Africa, } \\
\text { South Africa }\end{array}$ & $\begin{array}{l}\text { f Psychology } \\
\text { College of } \\
\text { iversity of } \\
\text { retoria, }\end{array}$ \\
\hline $\begin{array}{l}{ }^{4} \text { Department } \\
\text { and Technolog } \\
\text { Education, Un } \\
\text { South Africa, } \\
\text { South Africa }\end{array}$ & $\begin{array}{l}\text { f Science } \\
y \text {, College of } \\
\text { iversity of } \\
\text { retoria, }\end{array}$ \\
\hline $\begin{array}{l}\text { Correspondin } \\
\text { Ramodungoar } \\
\text { tabanrj@unis }\end{array}$ & $\begin{array}{l}\text { author: } \\
\text { e Tabane, } \\
\text { tac.za }\end{array}$ \\
\hline $\begin{array}{l}\text { Dates: } \\
\text { Received: } 21 \text { I } \\
\text { Accepted: } 15 \\
\text { Published: } 28\end{array}$ & $\begin{array}{l}\text { May } 2021 \\
\text { uly } 2021 \\
\text { Sept. } 2021\end{array}$ \\
\hline $\begin{array}{l}\text { How to cite th } \\
\text { Makola ZS, Sal } \\
\text { Tabane R, Muc } \\
\text { school learner } \\
\text { benefits derive } \\
\text { attending care } \\
\text { for sound care } \\
\text { J transdiscipl re } \\
2021 ; 17(1) \text {, a1 } \\
\text { org/10.4102/t }\end{array}$ & $\begin{array}{l}\text { is article: } \\
\text { we P, Dube I, } \\
\text { au AV. High } \\
\text { views on } \\
\text { d from } \\
\text { r talks: Need } \\
\text { r guidance. } \\
\text { S S Afr. } \\
\text { 882. https://doi. } \\
\text { I.v17i1.1082 }\end{array}$ \\
\hline Read online: & \\
\hline 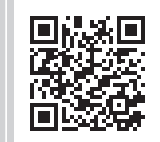 & $\begin{array}{l}\text { Scan this QR } \\
\text { code with your } \\
\text { smart phone or } \\
\text { mobile device } \\
\text { to read online. }\end{array}$ \\
\hline
\end{tabular}

Tertiary institutions in South Africa are experiencing alarming undergraduate drop-out rates. This has partly been attributed to students' inadequate preparation, and failure to gather information on, and planning for, their careers. The need for sound career guidance at the high school level is key, making the role of Life Orientation (LO) increasingly prominent. The aim of this study was to determine what benefits high school learners derive from attending career talks. To this end, a qualitative study was conducted with Grade 10 learners studying STEM (science, technology, engineering, and mathematics) at a township high school in Mamelodi, Tshwane. Data were collected using a qualitative questionnaire and analysed thematically. The findings demonstrated the importance of role models sharing information on their careers and work experiences. Another finding pertained to the importance of information on diverse careers, for the development of learners' career selfefficacy as students of STEM in a township high school context. The findings highlight the importance of LO teachers organising career workshops. The study will benefit the Department of Basic Education, businesses, and employers as key stakeholders, by helping to enhance the career development of future employees and entrepreneurs.

Keywords: career-related information; career talks; high school; life skills education; STEM education.

\section{Introduction}

Tertiary institutions in South Africa are experiencing alarming undergraduate drop-out rates. ${ }^{1}$ The first-year university drop-out ranges from $50 \%$ to $60 \%{ }^{2}$ It has been reported that $52 \%$ of learners made their career selection after Grade 12 , while $34 \%$ made concrete career decisions during registration at high education institutions. ${ }^{3}$ This shows that many Grade 12 learners have no or little idea of what they want to study or aspire to do post-school. ${ }^{3}$ According to Moodley and Singh, ${ }^{1}$ one in eight learners believe that because of the scarcity of career-related information at the relevant time, they did not make the right career choice The high drop-out numbers place an emotional strain on learners and parents alike, and such mismatches in turn have an impact on the economy. ${ }^{1}$ The need for sound career guidance at high school is therefore becoming increasingly clear, and is significantly serving to amplify the role of Life Orientation (LO) teachers. Vanin ${ }^{4}$ comments that career counsellors play a significant role in career selection choices of students, as is evident from growing concerns about the introduction and delivery of career counselling in high schools.

Career guidance is premised on the principle that learners who are exposed to career education will be properly prepared to make prudent career choices. The goal of career education is to improve a person's capacity to make informed career choices, based on his/her objectives, priorities, strengths, and goals. ${ }^{5}$ Although career expos are a key career engagement initiative for high school learners, it has been under-researched especially with learners in underprivileged high schools. Most research in this area is focused on college and university students. ${ }^{6,7}$ The purpose of the study was to investigate high school learners' views about the career talks they attended, with the aim to determining what benefits they derived from attending a career expo talk with the theme: 'Explore your options'.

\section{Literature review}

Since the early 1970s, the concept of career guidance has been widely used, but only recently it has been viewed as an inclusive method for managing someone's career throughout his/her entire

Copyright: ( 2021. The Authors. Licensee: AOSIS. This work is licensed under the Creative Commons Attribution License. 
lifetime. ${ }^{8}$ Career guidance and LO services are designed to support people of all ages, at any point in their lives, to empower them on an educational or vocational level, and in respect of their career choices, thereby allowing them to accomplish their career goals. ${ }^{9,10}$ There are three main elements in career guidance and LO services, namely: career information, career counselling, and career education, all of which equip people in terms of their future career choices. ${ }^{11}$

In most countries, schools continue to be the primary access points for formal career guidance. ${ }^{12}$ The value of schoolbased career education resides in its ability to reach a large number of people that are young. In schools, career guidance and LO typically concentrate on career information, by providing course information, outlining career paths, highlighting professions, and supplying information on the job market. ${ }^{13}$ Career education is usually divided into two categories in schools, that is in which students get knowledge of the working work and classroom exercises aimed at developing career management skills. (e.g. work experience).${ }^{14}$ Lastly, individual career counselling can advise groups or individuals in a one-to-one setting, while providing clear job choices and advice on making an informed decision. ${ }^{14}$

In general, career guidance is aimed at helping learners make choices based on their desires, passions, and skills, keeping in mind both present and future job prospects. Learners are motivated to gain a better understanding of the working environment by investigating a variety of industries, so that they can thereafter take correct actions to fulfil their ambitions, goals, and expectations. ${ }^{13}$ As Holman ${ }^{15}$ points out, career guidance facilitates knowledgeable decision-making, when choices must be made. It affords learners an opportunity to make better choices regarding the working environment, and to understand what credentials they will require to succeed.

In 21st-century South Africa, career guidance has been a crucial part of the educational process, as many young people from technologically deprived rural areas aspire to move from an agricultural lifestyle to an urban industrial and manufacturing environment. ${ }^{16}$ In urban economies, there is a growing range and quantity of job opportunities, meaning that younger people must make practical, educated, career decisions about schooling as well as training. Unfortunately, in the rural context, in most cases, young people end up making these decisions without the assistance of family or associated networks. ${ }^{17,18}$

Self-understanding is the main purpose of school guidance programmes. These guidance programmes help learners to learn about, recognise and exploit their aptitudes, interests, beliefs, and weaknesses, as result of a better sense of self. This improves their logical and strategic thinking, as well as their growth and development. ${ }^{19}$ Learners who know themselves are distinguished by their desire to establish more rational educational and occupational plans. ${ }^{20}$ Furthermore, career guidance should educate learners on a regular basis about jobs and job prospects. This means that schools, backed by visits from employers, must instil a love of work in students in their early years. A series of studies ${ }^{20,21}$ have shown the important effects which learner involvement in such events has on their potential (grown-up) experiences. Young people need to be able to gain access to legitimate labour market experiences, to obtain practical and accurate information about the world of work. This information must not only be delivered by employees or executives, but also professionals (from apprentices to Chief Executive Officers [CEOs]). Every interaction with people in the workforce allows young people to get a clearer grasp of how the job market works, how best they can adapt their career goals, and how they can relate their expectations to immediate schooling decisions. Employer involvement in career counselling usually includes events such as work or career fairs, network events and talks, career shadowing, work experience placements, training, and mentoring responsibilities. ${ }^{14}$

\section{Career guidance in South African public schools}

During the apartheid regime in South Africa (1948-1994), the education system for black learners was unpleasant and very limited. ${ }^{22}$ Black youths were constrained in terms of job choices, because of the insufficient content they were taught in their classes in high school. ${ }^{22}$ Career guidance was only accessible to white learners, who received lessons on job advice (every week for half an hour), as per legislation. The black learners, by contrast, received no such support. ${ }^{23}$ Nicholas et al..$^{24}$ explain that, for many years in this country, teachers' low preparation in terms of guidance and counselling in schools that are black and under-resourced has harmed career counselling.

The Higher Education Act 101 of 1997, was implemented after the advent of democracy in 1994, to address amongst other things, the dissimilarities in career guidance and education. ${ }^{25}$ Secondary school career development activities were identified as involving careers and career choices, which resort under ' $\mathrm{LO}^{\prime} .{ }^{26}$ Life Orientation is defined by the National Curriculum Statement (NCS) ${ }^{26}$ as the study of one's self in relation to everyone else and community. It covers self-awareness, environmental awareness, responsible citizenship, living a healthy and productive life, social involvement, recreation, and physical exercise, as well as careers and professional options.

The Department of Basic Education (DBE) $)^{27}$ claims that at the completion of Grade 9, learners make career choices when approaching grades 10, 11 and 12, by choosing subject fields. Learners have a choice of options which will determine their further study or work preferences from the end of Grade 12. During the foundation, intermediate and senior phases, provision is made for the subject Life Skills, as provided in the NCS for Grade R-12. ${ }^{27}$ According to the national DBE, ${ }^{27}$ provincial DBEs are responsible for career events which should be specifically targeted at Grade 12 learners, outside of school hours. Normally, such events comprise careerrelated exhibitions or talks which are presented by individuals working in a subject area. Other stakeholders like higher 
education and training universities, the National Youth Development Agency (NYDA), the Sector Education and Training Authorities (SETAs), non-governmental organisations (NGOs), private companies and Higher Education South Africa (HESA), take responsibility for organising career talks, exhibitions and career-related events. ${ }^{23}$

Schools in more affluent areas, which utilise the services of licenced psychologists, have well-developed career guidance procedures in place. ${ }^{28}$ Studies have found, nevertheless, that in numerous schools in less affluent areas, LO teachers lack expertise and experience in career guidance..$^{29,30,31}$ To resolve this issue, the DBE's provincial offices assist guidance and LO teachers by upskilling them by means of developing learning materials and offering approved training using private companies such as the PACE Career Centre. ${ }^{32}$

\section{Involving business in career guidance}

Bringing the classroom and the workplace together has broad public gains, but in practice, it can be difficult. ${ }^{33}$ Using data from the British Cohort Study of 1970, however, Kashefpakdel and Percy ${ }^{34}$ discovered a positive correlation between school-sponsored career talks with external presenters and the participant's predicted income when they are 26 years old. The study also found that career talks had a greater influence when presented to learners aged 14-15 years, than for those aged 15-16 years. Self-assessed teenagers frequently discovered such sessions 'unhelpful', 'helpful' 'very helpful' - responses which cover the full spectrum, without giving clear answers. Additionally, one to three career conversations over the course of a year have no discernible effect on pay, whereas 15 or more career talks, or even more than 30 discussions over the course of a year are connected with a higher compensation anticipated by projecting a linear relationship. ${ }^{34}$

In the 21st century, schools are faced with complex demands and limited resources to meet those demands, which forces schools and governments to look to outside partners to meet their needs. Globally, there has been a shift to more inclusive, collaborative, and holistic ways of working at the policy level. Schools cannot do it by themselves, and hence constantly seek community support for building capacity and enhancing educational outcomes. ${ }^{35,36}$ An increasing corpus of studies has evaluated and shown the crucial connections between youth employment outcomes and school-mediated employer engagement. ${ }^{20,37,38,39,40}$

Experience sharing by individuals at work is a good addition towards the forms of guidance services which are already offered to learners. Employers' participation in education is a strategic resource which schools can use to enhance learners' understanding of work and professions; give young individuals the skills and knowledge which the present-day labour market demands; and focus on providing youths with the skills and knowledge required for effective school-towork changes that stimulate education as well as support their achievements. ${ }^{20}$
Young people who are exposed to the workplace are better prepared to make decision about their own education and training. ${ }^{21}$ It helps them focus on the variety of career options and routes available to them. Working people have the potential to provide youngsters with perspectives and interactions that deliver distinct value - something which schools cannot duplicate. ${ }^{41,42}$ Young people are more willing to believe information obtained from employers representing a variety if occupations if they have first-hand experience with them. These encounters offer insights which learners generally feel are both reliable and wide-ranging, compared to the advice of their parents and friends (usually positive, but narrow in reach) or what they might glean from the internet or the media (seen as untrustworthy, and an information overload). This, at the very least, has the potential to reduce inconsistencies between career ambitions, educational options as well as competition in the labour market.

\section{Theoretical framework}

Bandura's ${ }^{43}$ Social Cognitive Career Theory (SCCT) is founded on how personal, behavioural and environmental factors interact in influencing a person's decisions. Rogers and Creed's ${ }^{44}$ SCCT focuses on the different behavioural and environmental factors that influence people's career choices. Those choices may be determined by the environment they come from, their personal aspirations, their personal capabilities, or their acquired knowledge.

Interactions with events and environmental factors can influence people's career decisions, altering or reinforcing personal choices and, indeed, career choices. Not only external influences should be considered, but factors such as internal cognitive, behavioural and physical attributes, as well as physical qualities are also relevant. ${ }^{45}$ The accumulation of information can assist someone in, or deter them from, making decisions about their career.

According to Schoenfeld et al., ${ }^{46}$ the career-based choices which people make are highly influenced by their judgement of how capable they will be in completing the tasks needed in a specific career. People sometimes choose careers that align with their abilities, but they might first look up the requirements and compare those to the skill sets they already possess. Gibbons et al. ${ }^{47}$ mention that the more people believe in their abilities, the more likely they are to choose a career which aligns with those abilities. However, those abilities should be complemented by an individual's interests and his/her personality.

The SCCT highlights how support for, or barriers to, an occupation can influence career choices. The more barriers a career path presents, the less likely it is that it will be a viable choice. ${ }^{48}$ Barriers could include: the cost of studying/fees; university entry requirements; the duration of the study; the attitude of the community as regards that career; the unavailability of career role models, etc. Someone who believes s/he can overcome the barriers presented by a particular occupation will not let those obstacles affect 
his/her career choice. ${ }^{47}$ Those individuals possess a high level of resilience (i.e. the capacity to face adversity in life, employment, education, yet to do well despite unfavourable conditions) ${ }^{49,50}$ Furthermore, financial support (e.g. bursaries and scholarships) sometimes make career choices easier, and that might prompt a learner to select a career which offers more financial support over the one that does not.

\section{Methodology}

To gain insight into learners' views of the career talks they attended at school, a questionnaire was used. The study applied a qualitative approach that adopted a phenomenological design, employing the interpretivist paradigm. ${ }^{51}$ Qualitative research enables researchers to deeply explore a subject's life experiences, behaviours and perspectives, and to uncover the intricacies of the situation under study. ${ }^{52}$ Creswell ${ }^{15}$ states that a phenomenological study 'describes the meaning for several individuals of their lived experiences of a concept or a phenomenon'. The emphasis is on explaining a phenomenon which the study participants experienced - in this instance, attending a career talk. The questionnaire used in this study was developed to determine the views and opinions of the learners about the first leg of a series of three career talks they were to attend. Their views and opinions were to be used when preparing the other career talks and were interrogated for academic research purposes.

\section{Participants and setting}

The career talks were given at a high school in Mamelodi township, to the east of the city of Tshwane, in South Africa. All Grade 10 learners who had selected STEM (Science, Technology, Engineering, and Mathematics) subjects, were invited to participate. Eleven speakers were invited to speak to the learners about their careers, under the theme 'Explore your options'. One speaker, from the field of agriculture, participated, even though that subject is not taught at the participating school. It nonetheless served to broaden the learners' thinking about that domain.

The purpose of the event was to bring together a variety of experts from STEM-related careers, to address the learners. In turn, the learners had an opportunity to interact with the presenters and obtain a real understanding of the post-school educational and career pathways which are open to them. The speakers not only discussed their chosen careers, but also their life history (where they grew up, their circumstances while growing up, and how they used education as a catalyst to change their lives and those of their families). Table 1 indicates the career fields which the speakers represented, as well as the race and gender of each speaker.

The research site was conveniently sampled, because of the Community Engagement Project, Tateni: Breaking the Cycle of Poverty (T-BCOP), in which the researchers are involved. At the end of the career talks, the researchers asked the volunteers to complete a paper-based questionnaire. The
TABLE 1: Demographics of speakers from different science, technology, engineering, and mathematics careers.

\begin{tabular}{|c|c|c|}
\hline Field & Race & Gender \\
\hline Civil engineering & Black person & Female \\
\hline Nanotechnology \& water sustainability & Black person & Male \\
\hline Emergency health services & White person & $\begin{array}{l}\text { One female and } \\
\text { one male }\end{array}$ \\
\hline Intellectual property law & Indian person & Female \\
\hline South African airforce & Black person & $\begin{array}{l}\text { One female and } \\
\text { one male }\end{array}$ \\
\hline Health laboratory services & Black person & Male \\
\hline Student admissions and registration & White person & Female \\
\hline Network \& cyber security & Black person & Male \\
\hline National space agency & Black person & Male \\
\hline Agricultural research & Black person & Female \\
\hline $\begin{array}{l}\text { Counselling and career development } \\
\text { services }\end{array}$ & Black person & Female \\
\hline
\end{tabular}

researcher explained the ethics around the research and reasons for completing the questionnaires.

\section{Research questions}

The questionnaire contained following three questions:

- What did you learn from the career talks?

- What was the best thing about the career talks?

- What were the bad things about the career talk?

These questions served as preconceived themes for this study, and were used as an analytical framework.

\section{Data collection and analysis}

From a population of 78 learners who attended the career talk, a sample of 21 learners volunteered to complete the questionnaire. All the participants were studying STEM subjects. The sample of learners was deemed sufficient Creswell and Poth ${ }^{51}$ recommend having 5-25 participants for phenomenological studies. The data were analysed thematically using Braun and Clarke' $\mathrm{s}^{54}$ six-step process, including: data familiarisation through reading and colourcoding participants' responses according to similarity; generating initial codes where similar responses were coded together; sorting codes into broader categories through identifying commonalities and differences to establish emerging sub-themes, which resulted in themes 1 and 2 being combined; reflecting and redefining themes in discussion with the study's authors and with reference to excerpts; considering their coherence and inter-relationships in which the sub-themes were reviewed continually for relevance and coherence, before being finalised.

\section{Ethical considerations}

Ethics clearance was obtained through the University of South Africa (clearance number: 2017/02/15/90179617/04/ $\mathrm{MC})$. The purpose of the study was clearly explained to the participants. Each participant gave individual consent for participating in the information and Q\&A session. No names were recorded, and participants were informed of their right to leave the at any time if they so wished. 


\section{Findings and discussion}

Three themes which emerged from the data on the benefits of attending the career talks, related to whether the learners felt motivated by the speakers, the information they gained on different careers, as well as how to choose a career. Each of these aspects is discussed in detail below.

\section{Motivation}

Most participants indicated that they were positively motivated by the speakers. One participant said:

'... what drives people's passion and desire for such choices, and it deeply motivated [me] to know that from any position or background I'm coming from, I can do it!' (Learner 7, black person, gender undisclosed)

Another stated:

'I learnt that in life you must set your eyes on your goals. You must [keep] this in mind, if you can dream about it, then you can hold it in your hands and pursue your dream. I learnt that you must be ambitious and have passion.' (Learner 13, black person, gender undisclosed)

Given the lack of career role models, many learners in disadvantaged communities are faced with difficult issues such as dropping out of school, teenage pregnancy, or hopelessness which unattended can lead to suicide. ${ }^{22}$ Many abandon their education or stop pursuing a career due to low self-efficacy. ${ }^{22}$ For that reason, role models are important, as they can have a substantial influence on learners' self-efficacy which, in turn, can affect their career development. In the present study, the speakers served as role models for the participants, especially since most were the same race or gender, thus facilitating the mirror effect, where learners can see themselves as being equally capable of entering the presented careers. Gauntlett, ${ }^{55}$ defines a role model as 'someone to look up to and base your character, values and aspirations on'. McIntyre et al. ${ }^{56}$ describe role models as 'successful members of one's own group'. Therefore, it is not surprising that the learners felt motivated by African speakers who hailed from similar backgrounds to them. The learners could thus possibly have identified with the speakers and envisaged their own future selves in the speakers. Literature shows that the presence of career role models is associated with positive outcomes (e.g. increased motivation) for minorities in STEM fields, ${ }^{57}$ and more positive beliefs about their future success. ${ }^{58,59}$ Thus, as reported by Dodge and Welderufael, ${ }^{60}$ participants indicated a need for role models to help them find meaningful careers. Role models from disadvantaged areas could further assist learners to conquer their own histories and whatever negative effects they experience in their communities, to improve their selfefficacy. ${ }^{61}$ Thus, having role models improves a learner's career self-efficacy. Also, having black role models who are in a STEM field is important for encouraging more learners into related careers, thereby increasing the underrepresentation of blacks in those domains. ${ }^{62}$

\section{Information on different careers}

Most participants shared that they learned about different careers during the talks. As articulated by Learner 12,

'I learnt that there are a lot of careers in this world.' (Learner 12, black person, gender undisclosed)

Some participants stated that the information they received expanded their existing knowledge of careers. As some participants stated:

'I learnt that there are different types of civil engineers.' (Learner 14, black person, gender undisclosed),

'I got to know that different types of careers [exist] in agriculture; I also learned more information and things on the [medical] field.' (Learner 12, black person, gender undisclosed)

In addition to broadening their existing knowledge, some participants mentioned learning about new careers:

'I learned about different careers and their advantages. I learned a lot of things I didn't know about.' (Learner 15, black person, gender undisclosed)

'I learnt about career choices that I [didn't] know [about].' (Learner 14 , black person, gender undisclosed)

These findings support the notion that inviting working professionals to discuss their careers is beneficial for learners, because research shows that the latter are more prone to believe the first-hand information they receive about varied occupations. ${ }^{20,42}$ Such encounters provide learners with information which they feel is both detailed and reliable - more so than the advice obtained from parents and friends. This can theoretically reduce the misalignment of professional ambitions, academic choices, and labour market demand. ${ }^{14}$ These findings confirm those of Dodge and Welderufael, ${ }^{60}$ that high school learners want experienced workers to come to their schools to talk to them about different careers.

This links to the previous finding on the importance of selfefficacy. Research shows that the more career information someone has, the higher his or her career expectations will be. ${ }^{63,64}$ This finding thus confirms that when learners receive career information from role models, it increases their efficacy with respect to making a career decision.

\section{Choosing a career}

Many participants said they learned how to go about choosing their careers.

'I was also [taught] more on how to choose a career.' (Learner 2, black person, gender undisclosed)

'I learned how to choose a career' (Learner 5, black person, gender undisclosed).

Several participants mentioned learning that the monetary aspect of a career was not the most important factor to consider: 
'I learned that your career is not about the money, but the passion.' (Learner 3, black person, gender undisclosed)

'I learnt to choose wisely and make decision[s] that will work to my advantage, and not look at the income but the goods it will bring.' (Learner 16, black person, gender undisclosed)

'I learned that I should choose my career according to my talent and dream.' (Learner 19, black person, gender undisclosed)

As noted by Edward and Quinter ${ }^{65}$ and Perrone et al., ${ }^{66}$ learners' interests provide the main motives or influence for their career choice. When choosing careers, most learners consider their interests, thus their choice might not always be influenced by their circumstances or home background. This is important because matching personal interest with a career choice often leads to job satisfaction. ${ }^{65}$ The implication is therefore that the study participants were likely to remain in the STEM career field, rather than choosing to opt out. Therefore, career interests and choices are partly dependent on self-efficacy expectations, while learners' expectations are developed if they have access to sources that reinforce their self-efficacy expectations. ${ }^{67}$

Two themes emerged from the data on the drawbacks of attending the career talks. These were time spent at the career talks as well as unmet expectations.

\section{Time spent at the career talks}

Several learners indicated that the time they spent at the career talks was long.

'They kept us here for a long time.' (Learner 1, black person, gender undisclosed)

'They took so much time, I was starving.' (Learner 14, black person, gender undisclosed)

'We came out late.' (Learner 5, black person, gender undisclosed)

This finding indicated the need for sufficient breaks during the career talks. This ensures that learners remain comfortable throughout the event and are able to retain information being shared and do not experience information overload. ${ }^{68,69}$

\section{Unmet expectations}

A few learners indicated that some of the careers they expected to learn about were not included in the career talks.

'Some of the careers we expected to learn about we were not given information on.' (Learner 17, black person, gender undisclosed)

\section{Similarly, Learner 21 reported that}

'My career was not included.' (Learner 21, black person, gender undisclosed)

This finding points to the need for learners' input on the careers they would like information on. Obtaining learners input is also recommended by Payne and Sumter. ${ }^{70}$ Although learners' input is important, it must be noted that organisers of career talks should also provide information that may not be easily accessible to learners, for example, lesser known careers and new careers, because changes such as the 4th Industrial Revolution (4IR) requires new set of skills.

\section{Conclusion}

This study has demonstrated the importance of role models, comprehensive career information, and career interests and choices, in the development of career efficacy in STEM learners in a high school context. It can thus be concluded that events (such as career talks) which are directed at high school learners will be beneficial to them. Critically, career talks are more effective when conducted with professionals in the field sharing their journeys, since that encourages learners to select and pursue similar career paths. The findings in this study also point to the need for organisers of careers talks to ensure enough breaks are included in the career talks' schedule so learners do not suffer from mental fatigue as well as gathering input from learners on the careers they would like to learn about. However, when colleting input from learners, organisers must also include lesser-known careers in their schedules to broaden learners' information and knowledge on these careers.

This study's findings can be beneficial to the DBE, because it indicates the importance of stakeholder relationships in enhancing career-related learning and development. Additionally, the national DBE and especially the provincial DBEs would benefit from creating relationships with local and national businesses and organisations for the purpose of providing career talks to learners. This would assist the LO teachers because they lack experience and skills in career guidance. The LO teachers would then play the role of being a facilitator of the career talks event in their schools. Additionally, the career talks event could be imbedded within the LO lessons.

For businesses and employers, the findings are beneficial because they show that organisations can benefit from participating in career talks because they play a role in shaping the future skills supply for their industries and organisation, especially in fields where there are critical skills shortages such as the STEM-field.

limitation of this study was that a small sample was used, therefore the findings cannot be generalised. A larger sample could be used in future studies, to allow for a more comprehensive analysis and programme to be designed (with ample breaks, so that learners do not experience information overload). Mental fatigue may have been a reason for the low number of learners who completed the questionnaire on the day.

\section{Acknowledgements}

The authors would like to thank the school and all the speakers of the career talk day. 


\section{Competing interests}

The authors declare that they have no financial or personal relationships that may have inappropriately influenced them in writing this article.

\section{Authors' contributions}

All authors contributed equally to this work.

\section{Funding information}

The data collection for this article was funded by University of South Africa (UNISA) Community Engagement directorate. The authors acknowledge the support provided by McDonalds SA during the career guidance talk.

\section{Data availability}

The data that support the findings of this study are available from the corresponding author, R.T., upon reasonable request.

\section{Disclaimer}

The views and opinions expressed in this article are those of the authors and do not necessarily reflect the official policy or position of any affiliated agency of the authors.

\section{References}

1. Moodley P, Singh RJ. Addressing student dropout rates at South African universities [homepage on the Internet]. 2015 [cited 2021 May 12]. Available from: https://openscholar.dut.ac.za/handle/10321/1648

2. Fundiconnect. 9 reasons students drop out of university | Fundiconnect [homepage on the Internet]. 2021 [cited 2021 Jul 12]. Available from: https:// www.fundi.co.za/fundiconnect/student-dropout-causes/

3. Singh N. Career guidance needs of post secondary learners who utilised a caree advice services helpline [homepage on the Internet]. 2016 [cited 2021 Jul 13]. Available from: https://www.semanticscholar.org/paper/Career-guidance-needs-ofpost-secondary-learners-a-Singh/f22a229c7a13fa04c6d627d0be7a417c930365e2

4. Vanin G. The role of a career counsellor in enhancing the career development process of secondary school students. Doctoral thesis, Australian Catholic University; 2015.

5. Nota L, Soresi S, Ferrari L, Ginevra MC. Vocational designing and career counseling in Europe. Eur Psychol. 2014;19(4):248-259. https://doi.org/10.1027/1016-9040/ a000189

6. Lee M, Lee PC, Dopson LR, SungSik Y. What dimensions of career expos have the most impact on student satisfaction? J Hosp Leis Sport Tour Educ. 2020;27:100263. https://doi.org/10.1016/j.jhlste.2020.100263

7. Stonebraker I, Maybee C, Chapman J. Undergraduate students' experiences of using information at the career fair: A phenomenographic study conducted by the libraries and career center. J Acad Librariansh. 2019;45(4):358-367. https://doi. org/10.1016/j.acalib.2019.05.002

8. Niles SG, Harris-Bowlsbey J, Del Corso J. Career development interventions in the 21st century. 4th edition. Hoboken, NJ: Pearson; 2013.

9. Ajufo BI. Challenges of youth unemployment in Nigeria: Effective career guidance as a panacea. Afr Res Rev. 2013;7(1):307-321. https://doi.org/10.4314/afrrev.v7i1.21

10. Maree JG. Latest developments in career counselling in South Africa: Towards a positive approach. S Afr J Psychol. 2013;43(4):409-421. https://doi.org/10.1177/ 0081246313504691

11. Watts AG. Career guidance and orientation. In: Germany: UNESCO-UNEVOC International centre for technical and vocational education and training, editor. UNESCO-UNEVOC, Revisiting global trends in TVET: Reflections on theory and practice [homepage on the Internet]. 2013 [cited 2020 Jun 14]; p. 239-274. Available from: http://www.tecnicoprofesional.mineduc.cl/wp-content/uploads/ 2016/08/Revisiting-Global-Trends-in-TVET.pdf\#page=249

12. CEDEFOP. Skills forecast [homepage on the Internet]. 2016 [cited 2021 May 12] Available from: https://www.cedefop.europa.eu/en/publications-and-resources/ data-visualisations/skills-forecast

13. Van NT, Loan DTB. Career guidance in secondary schools - A literature review and strategic solutions for Vietnamese rural areas. Res Rev: J Educ Stud [serial online] 2016 [cited 2021 May 12];2(3). Available from: https://www.rroij.com/peerreviewed/career-guidance-in-secondary-schools-a-literature-review-andstrategic-solutions-for-vietnamese-rural-areas-80165.html
14. Musset $P$, Kurekova LM. Working it out: Career guidance and employer engagement [homepage on the Internet]. 2018 [cited 2021 May 12]. Available from: https://www.oecd-ilibrary.org/education/working-it-out_51c9d18d-en

15. Holman J. Good career guidance [homepage on the Internet]. London: The Gatsby Foundation; 2014 [cited 2021 May 12]. Available from: http://www.gatsby.org.uk/ uploads/education/reports/pdf/gatsby-sir-john-holman-good-career-guidance2014.pdf

16. Dabula P, Makura AH. High school students' perceptions of career guidance and development programmes for university access. Int J Educ Sci. 2013;5(2):89-97. https://doi.org/10.31901/24566322.2013/05.02.01

17. Fox L, Kaul U. The evidence is in: How should youth employment programs in low income countries be designed? [homepage on the Internet]. Rochester, NY: Socia Science Research Network; 2018 [cited 2021 Jul 13]. Available from: https:// papers.ssrn.com/abstract $=3238339$

18. Spaull N. Schooling in South Africa: How low-quality education becomes a poverty trap. S Afr Child Gauge. 2015;12(1):34-41

19. Hendricks EA, Thengela $\mathrm{N}$. The role of education in alleviating poverty, inequality and promoting economic development in South Africa. Afr J Dev Stud. 2020;10(3):215-234. https://doi.org/10.31920/2634-3649/2020/10n3a11

20. Mann A, Rehill J, Kashefpakdel ET. Employer engagement in education: Insights from international evidence for effective practice and future research [homepage on the Internet]. London: Education Endowment Foundation; 2018 [cited 2020 Jun 13]. Available from: https://educationendowmentfoundation.org.uk/public/ files/Employer_Engagement_in_Education.pdf

21. Rehill J, Kashefpakdel ET, Mann A. How to make the most of careers events with employers: Technical report. London: Education and Employers; 2017.

22. Buthelezi T, Alexander D, Seabi J. Adolescents' perceived career challenges and needs in a disadvantaged context in South Africa from a social cognitive caree theoretical perspective. J High Educ. 2009;23(3):505-520. https://doi.org/ 10.4314/sajhe.v23i3.51033

23. Sefora S. Grade 12 learners' narratives of career choice and guidance at a South African high school [homepage on the Internet]. 2016 [cited 2021 May 12] Available from: http://uir.unisa.ac.za/handle/10500/22047

24. Nicholas L, Naidoo A, Pretorius T. A historical perspective of career psychology in South Africa. In Career psychology in the South African context. Van Schaik. 2006; pp. 1-10.

25. South Africa. The Higher Education Act 101 of 1997. Pretoria: Government Printers; 1997.

26. Department of Basic Education. National curriculum statements grades R-12 [homepage on the Internet]. Pretoria: Department of Basic Education; 2019 [cited 2020 Jun 10]. Available from: https://www.education.gov.za/Curriculum/ NationalCurriculumStatementsGradesR-12.aspx

27. Department of Basic Education. Annual Report 2011/12 [homepage on the Internet]. Pretoria: Department of Basic Education; 2012 [cited 2020 Jun 10]. Available from: https://www.gov.za/sites/default/files/gcis_document/201409/ dbe-annual-report-2012ab.pdf

28. September U. Evaluating the perceptions and use of computer assisted career guidance systems in seven high schools by learners and teachers: Analysis, synthesis and computer effect [homepage on the Internet]. 2017 [cited $2021 \mathrm{Ju}$ 13]. Available from: https://open.uct.ac.za/handle/11427/25459

29. Pillay J. Keystone life orientation (LO) teachers: Implications for educational, social, and cultural contexts. S Afr J Educ. 2012;32(2):167-177. https://doi. org/10.15700/saje.v32n2a497

30. Diale B, Pillay J, Fritz E. Dynamics in the personal and professional development of life-orientation teachers in South Africa, Gauteng province. J Soc Sci. 2014;38(1):83-93. https://doi.org/10.1080/09718923.2014.11893239

31. Smith KA, Harrison A. Teachers' attitudes towards adolescent sexuality and life skills education in rural South Africa. Sex Educ. 2013;13(1):68-81. https://doi.org 10.1080/14681811.2012.677206

32. SAQA. Skills Development Act 97 of 1998, section 54(1). Government Printers: Pretoria; 2010.

33. Torii K. Why school kids need more exposure to the world of work [homepage on the Internet]. 2018 [cited 2021 May 12]. Available from: https://theconversation. com/why-school-kids-need-more-exposure-to-the-world-of-work-100590

34. Kashefpakdel ET, Percy C. Career education that works: An economic analysis using the British Cohort Study. J Educ Work. 2017;30(3):217-234. https://doi.org/ 10.1080/13639080.2016.1177636

35. Zenda R. Implementing a parental involvement policy to enhance physical sciences learner's academic achievement in rural secondary schools. Educ Res Policy Pract. 2021;20(2):125-143. https://doi.org/10.1007/s10671-020-09275-5

36. Epstein JL, Sanders MG, Sheldon SB, et al. School, family, and community partnerships: Your handbook for action. Thousand Oaks, CA: Corwin Press; 2018.

37. Kemple JJ, Willner CJ. Career academies: Long-term impacts on labor market outcomes, educational attainment, and transitions to adulthood. New York, NY: MDRC; 2008

38. Massey D. The economic case for employers. In: Mann A, Stanley J, Archer L, editors. Understanding employer engagement in education: Theories and evidence. London: Routledge, 2014; p. 236.

39. Neumark D, Rothstein D. Do school-to-work programs help the 'forgotten half'? [homepage on the Internet]. National Bureau of Economic Research; 2005 [cited 2021 May 12]. Available from: https://www.nber.org/papers/w11636

40. Percy C, Mann A. School-mediated employer engagement and labour market outcomes for young adults. In: Mann A, Stanley J, Archer L, editors. Understanding Employer Engagement in Education: Theories and Evidence. Routledge, 2014; p. 205. 
41. Mann A, Kashefpakdel ET, Rehill J, Huddleston P. Contemporary transitions: Young Britons reflect on life after secondary school and college. Education and Young Britons reflect on life after
Employers Research. 2016 Jun.

42. Stanley J, Mann A. A theoretical framework for employer engagement. In: Mann A, Stanley J, Archer L, editors. Understanding employer engagement in education Theories and evidence. London: Routledge, 2014; p. 236.

43. Bandura A. Social cognitive theory: An agentic perspective. Annu Rev Psychol. 2001;52(1):1-26. https://doi.org/10.1146/annurev.psych.52.1.1

44. Rogers ME, Creed PA. A longitudinal examination of adolescent career planning and exploration using a social cognitive career theory framework. J Adolesc. 2011;34(1):163-172. https://doi.org/10.1016/j.adolescence.2009.12.010

45. Dickinson J, Abrams MD, Tokar DM. An examination of the applicability of social cognitive career theory for African American College Students. J Career Assess. 2017;25(1):75-92. https://doi.org/10.1177/1069072716658648

46. Schoenfeld J, Segal G, Borgia D. Social cognitive career theory and the goal of becoming a certified public accountant. Account Educ. 2017;26(2):109-126. https://doi.org/10.1080/09639284.2016.1274909

47. Gibbons MM, Hyfantis J, Cihak DF, Wright R, Mynatt B. A social-cognitive exploration of the career and college understanding of young adults with intellectual disabilities. Prof Sch Couns. 2015;19(1):80-91. https://doi.org/10.5330/1096-2409-19.1.80

48. Inda M, Rodríguez C, Peña JV. Gender differences in applying social cognitive career theory in engineering students.

49. Mampane MR. Factors contributing to the resilience of middle-adolescents in a South African township: Insights from a resilience questionnaire. S Afr J Educ. 2014;34(4):1-11. https://doi.org/10.15700/saje.v38n4a1636

50. Van Breda A, Theron L. A critical review of South African child and youth resilience studies, 2009-2017. Children Youth Serv Rev. 2018;91:237-247. https://doi. org/10.1016/j.childyouth.2018.06.022

51. Creswell JW, Poth CN. Qualitative inquiry and research design: Choosing among five approaches. Thousand Oaks, CA: Sage; 2018.

52. Holloway I, Wheeler S. Qualitative research in nursing and healthcare. Hoboken, NJ: Wiley; 2010.

53. Creswell JW. Research design: Qualitative, quantitative, and mixed methods approaches. 3rd edition. Thousand Oaks, CA: Sage; 2009.

54. Braun V, Clarke V. Using thematic analysis in psychology. Qual Res Psychol. 2006;3(2):77-101. https://doi.org/10.1191/1478088706qp063oa

55. Gauntlett D. Media, gender and identity: An introduction. 2nd edition. 2002.

56. McIntyre RB, Paulson RM, Taylor CA, Morin AL, Lord CG. Effects of role model deservingness on overcoming performance deficits induced by stereotype threat Eur J Soc Psychol. 2011;41(3):301-311. https://doi.org/10.1002/ejsp.774

57. Aish N, Asare P, Miskioğlu EE. People like me: Providing relatable and realistic role models for underrepresented minorities in STEM to increase their motivation
and likelihood of success. In 2018 IEEE integrated STEM education conference (ISEC). IEEE, 2018; p. 83-89.
58. BarNir A, Watson WE, Hutchins HM. Mediation and moderated mediation in the relationship among role models, self-efficacy, entrepreneurial career intention, and gender. J Appl Soc Psychol. 2011;41(2):270-297. https://doi.org/10.1111/ j.1559-1816.2010.00713.x

59. Dasgupta N. Ingroup experts and peers as social vaccines who inoculate the selfconcept: The stereotype inoculation model. Psychol Inq. 2011;22(4):231-246. https://doi.org/10.1080/1047840X.2011.607313

60. Dodge $E$, Welderufael M. Factors that influence career choice in South African township high school students [homepage on the Internet]. Graduate Master's theses, capstones, and culminating projects. 2014 [cited 2020 Jun 17]. Available from: https://scholar.dominican.edu/masters-theses/7

61. Matshabane OP. Exploring the influence of role models on the career development process of school-going adolescents from a low-income community in South Africa [homepage on the Internet]. 2016 [cited 2021 Jul 12]. Available from: https://scholar.sun.ac.za:443/handle/10019.1/100356

62. Funk C, Parker K. Women and men in STEM often at odds over workplace equity [homepage on the Internet]. Pew Research Center's Social \& Demographic Trends Project; 2018 [cited 2021 May 12]. Available from: https://www.pewresearch. org/social-trends/2018/01/09/women-and-men-in-stem-often-at-odds-overworkplace-equity/

63. Darmayanti KKH, Prasetyo DT, Winata EY, Sakti P. What will you do after graduated from university? Increasing career decision self-efficacy through career counseling. JKKP. 2020;7(1):26-37. https://doi.org/10.21009/JKKP.071.03

64. Baglama B, Uzunboylu $\mathrm{H}$. The relationship between career decision-making selfefficacy and vocational outcome expectations of preservice special education teachers. S Afr J Educ. 2017;37(4):a1520. https://doi.org/10.15700/saje. v37n4a1520

65. Edwards K, Quinter M. Factors influencing students career choices among secondary school students in Kisumu municipality, Kenya [homepage on the Internet]. 2011 [cited 2021 May 12]. Available from: https://journals.co.za/doi/10.10520/ EJC135714.

66. Perrone KM, Sedlacek WE, Alexander CM. Gender and ethnic differences in career goal attainment. Career Dev Q. 2001;50(2):168-178. https://doi.org/10.1002/ j.2161-0045.2001.tb00981.x

67. Falco LD, Summers JJ. Improving career decision self-efficacy and STEM selfefficacy in high school girls: Evaluation of an intervention. J Career Dev. 2019;46(1):62-76. https://doi.org/10.1177/0894845317721651

68. Maddox K. The effects of brain breaks in a classroom [homepage on the Internet]. 2019 [cited 2021 Jul 12]. Available from: https://mdsoar.org/handle/11603/13870

69. Morton S. Engagement through brain breaks in the secondary classroom [homepage on the Internet]. MSEd in Educational Leadership Research Projects;
2016 [cited]. Available from: https://scholarworks.umf.maine.edu/ed_leadership_ projects/39

70. Payne BK, Sumter M. College students' perceptions about career fairs: What they like, what they gain, and what they want to see. Coll Stud J. 2005;39(2):269. 